\title{
MEMBANGUN SISTEM INTEROPERASIBILITAS SISTEM OPERASI LINUX DAN WINDOWS DENGAN MEMANFAATKAN TEKNOLOGI SAMBA
}

(The Development of Interoperation of Operating System Linux and Windows by Utilizing Samba Technology)

\author{
Mufadhol \\ Fakultas Teknologi Informasi dan Komunikasi Universitas Semarang
}

\begin{abstract}
At this time many used different of operating system on computer system. to interoperation the two different of operating system required auxiliary of software. Samba of technology as a software which will help as relation between Linux operating system and Windows operating system. Before performing the data sharing and printer sharing is necessary to take measures so that sharing can be done with perfect such : (1) Installation of Samba, (2) Make User of Samba, (3) Configuration of Samba, such : (a) through shell, (b) Xwindows, (c) Browser. (4) activation of Samba. File sharing and print sharing in Linux operating system and Windows opeating system on computer network can be used easily and regularly.
\end{abstract}

Keyword : Interoperation, Diferent, Operating System, Samba.

\section{PENDAHULUAN}

Perkembangan jaringan komputer saat ini begitu pesat. Seiring dengan perkembangan tersebut, kebutuhan user akan kualitas jaringan semakin meningkat baik itu LAN ataupun WAN. Kualitas yang dimaksud adalah jaringan komputer yang terbebas dari masalah seperti pengiriman data yang lambat, koneksi yang tidak stabil, dan sebagainya sehingga secara tidak langsung dapat mengurangi produktivitas kerja. Koneksi jaringan komputer merupakan suatu hal yang mendasar dalam suatu jaringan, karena bila koneksi itu bermasalah maka semua jenis aplikasi yang dijalankan melalui jaringan komputer tidak dapat digunakan.

Saat ini banyak digunakan sistem operasi yang berbeda pada sistem komputer, begitu juga dalam sebuah jaringan terdapat beberapa sistem komputer yang menggunakan sistem operasi yang berbeda contohnya dalam suatu jaringan local pada server menggunakan sistem operasi Linux sedangkan pada client menggunakan sistem operasi Windows. Jika suatu jaringan menggunakan sistem operasi yang sama tidak begitu sulit untuk melakukan hubungan sehingga dengan terhubungnya suatu jaringan dapat dilakukan beberapa aplikasi seperti sharing file, sharing data, sharing printer dan sebagainya. Misalnya pada jaringan yang menggunakan sistem operasi yang sama yaitu sistem operasi Windows, hanya mengkonfigurasi IP-Addressnya setelah itu dishare mana yang diinginkan. Tetapi apabila suatu jaringan menggunakan dua buah sistem operasi yang berbeda maka perlu dibuat langkah-langkah kerja untuk melakukan sharing sehingga sistem operasi Linux dapat terhubung dengan sistem operasi Windows.

Dalam membuat langkah-langkah kerja untuk menghubungan kedua sistem operasi yang berbeda ini diperlukan software pembantu. Karena itu dipilihlah Teknologi Samba sebagai software yang akan membantu sebagai penghubung antara sistem operasi Linux dengan sistem operasi Windows, Teknologi Samba menjadi pilihan karena saat ini teknologi samba sedang populer dan banyak digunakan baik diinstansi 
pemerintahan maupun didunia industri sehingga tidak terlalu sulit untuk mendapatkan Samba.

\section{METODE}

Sebelum melakukan sharing data dan printer perlu diambil langkah-langkah agar sharing dapat dilakukan dengan sempurna diantaranya :

1. Instalasi Samba

Instalasi dapat dilakukan dengan menggunakan cara intalasi dari kode sumber dan intalasi degan paket RPM.

2. Membuat User Samba

Membuat user Samba tujuannya adalah agar layanan Samba dapat diakses.

3. Membuat konfigurasi Samba

Melakukan konfigurasi Samba dapat dilakukan melalui 3 cara yaitu :

a. Melalui terminal (shell)

b. Xwindows

c. Browser (SWAT).

4. Mengaktifkan Samba

Mengaktifkan Samba adalah langkah terakhir dalam melakukan Sharing data dan printer pada sistim operasi Linux dan Windows dalam suatu jaringan.

\section{LANDASAN TEORI}

\subsection{Jaringan Komputer}

Jaringan komputer adalah sebuah kumpulan komputer, printer dan peralatan lainnya yang terhubung dan saling berhubungan antara yang satu dengan yang lain untuk melakukan tugas-tugasnya (Binanto, 2007) . Dua komputer atau lebih, dapat dikatakan saling terkoneksi jika komputerkomputer tersebut dapat saling bertukar informasi melalui berbagai media transmisi. Jaringan komputer pada dasarnya adalah penggabungan antara dua teknologi yaitu teknologi komputer dan teknologi komunikasi, dimana penggabungan tersebut menghasilkan sebuah teknologi komunikasi data yang bisa diaplikasikan dalam komputer. TCP/IP merupakan kumpulan protokol yang dibangun agar semua komputer dengan berbagai ukuran, dari berbagai vendor komputer yang berbeda dan berjalan dengan sistem operasi yang berbeda untuk dapat saling berkomunikasi satu sama lain (Utomo, 2006).

\subsection{Samba}

Samba dapat menjembatani kompleksitas berbagai platform sistem operasi Linux (UNIX) dengan mesin yang bersistem operasi Windows yang dijalankan dalam suatu jaringan (Purbo, 2002). Samba merupakan aplikasi dari Unix dan Linux, yang dikenal dengan SMB (Server Massege Blok) protocol. Banyak sistim operasi seperti Windows dan OS/2, menggunakan SMB untuk menciptakan jaringan client-server. Protokol Samba memungkinkan server Unix maupun Linux dapat berkomunikasi dengan protocol dari produk Microsoft Windows dalam satu jaringan. Dengan Samba sistem operasi Linux/Unix dianggap sebagai PDC (Primary Domain Controller) sebagaimana yang dilakukan NT dalam jaringan Microsoft Windows. Dengan menggunakan teknologi samba client Windows dalam server Linux/Unix dapat berkomunikasi seperti : dapat saling berbagi satu atau lebih file sistem (file sharing), berbagi fasilitas seperti printer yang terinstal baik pada server maupun clientnya (printer sharing), membantu clients browsing di Network Neighborhood, membantu otorisasi tiap clients untuk dapat login ke Windows domain serta dapat membantu atau memberikan dengan WINS nama server resolution. 


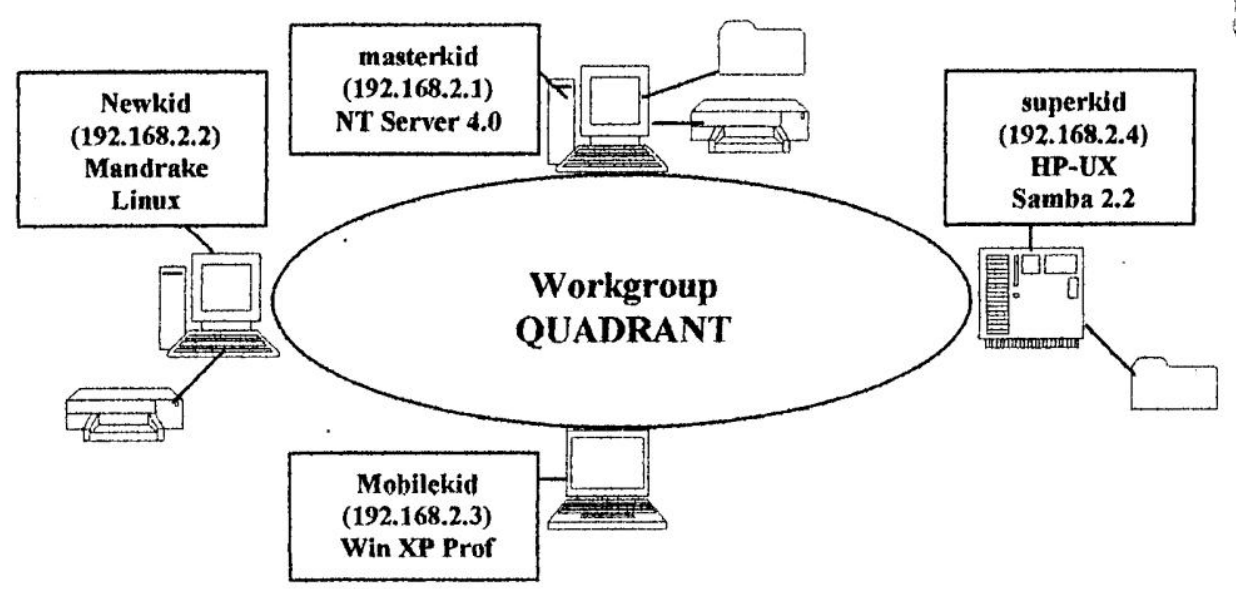

Gambar 1. Penggunaan Samba pada lingkungan heterogen

Gambar tersebut menunjukkan sebuah jaringan dengan model workgroup dengan nama workgroup QUADRANT. Apabila program Samba sudah terinstal pada mesin newkid (Mandnrake Llinux) dan superkid (HPUX), komputer masterkid dan mobilekid yang berbasis Windows dapat menggunakan printer yang berada di komputer newkid, serta mengakses file yang berada di komputer superkid, begitu pula komputer newkid dan superkid dapat menggunakan printer dan mengakses file yang berada di komputer masterkid. Jika diinginkan sebuah otentifikasi dan pengendalian sumber daya yang terpusat, model workgroup tersebut dapat diubah menjadi model NT domain dengan menempatkan sebuah Primary Domain Controller (PDC) di mesin masterkid (Windows NT Server 4.0) atau dapat dengan menempatkannya di mesin newkid (Linux Mandrake dengan Samba 2.2).

\subsection{Sejarah Samba}

Diawali oleh IBM dan Sutee yang mengembangkan sebuah sistem NetBIOS (Network Basic Input/Output System), NetBIOS ini merupakan perangkat lunak yang menjadi perantara antara program dan perangkat keras jaringan. Kemudian Microsoft menambahkan sebuah fitur berupa I/O redirection, sehingga sebuah sumber daya lokal (printer, harddisk) dapat diakses oleh komputer lain yang masih berada dalam satu jaringan komputer. MS-DOS Client, dengan perintah Net Use Drive:Ilcomputer namelshare name atau Windows dengan perintah Map Network Drive. Kedua perintah ini akan membuat sebuah sumber daya remote di komputer lain seolah-olah berada di komputer yang dituju.

Samba dikembangkan pertama kali oleh Andres Tridgell pada tahun 1991, pada saat itu ia mendapat sebuah utilisasi bernama Digital Paghworks, yang merupakan satu utilitas MSDOS untuk melakukan mounting ke server digital UNIX. Sayangnya saat itu Tridgell tidak bisa melakaukan hal yang sama ke mesin Solaris. Kemudian, ia berpikir untuk mengembangkan SMB untuk UNIX.

Andrew Tridgell mengawali idenya untuk mencoba mengakses file di mesin Windows istrinya dari mesin Unix miliknya tahun 1991. pada tahun 1992 Tridgell pun menemukan satu varian baru dari Unix yang dikembangkan seorang Finlandia, Linus Torvalds, dan bernama Linux. Varian ini memiliki kelebihan dalam keterbukaan kode asal (source code), serta dikembangkan oleh ribuan orang, maka Tridgell memilih untuk menggunakan Linux. Masih di tahun yang sama pada saat Torvalds bersama dengan Tridgell inilah terjadi satu "Tragedi Penguin", kejadian yang menyebabkan logo dari Linux adalah penguin, yaitu pada saat Torvalds dikejar dan di patuk oleh seekor penguin di sebuah kebun binatang di Canberra. Pada saat itu Torvalds tengah mengunjungi Tridgell. 
Perkembangan Samba selanjutnya dibentuk Tim Samba yang bekerja di rumah Tridgell di Camberra, dan disponsori oleh Australia National University, tempat ia mendapatkan gelar Ph.D. saat ini Samba dikembangkan sebagai bagian dari Open Source Software (OSS) dan didistribusikan di bawah lisensi GNU General Public License (GPL). Literatur lengkap tentang GNU dapat diperoleh pada http://www.gnu.org (Purbo, 2002).

\subsection{Windows}

Window adalah sebagian dari sistem operasi yang mengawali proses dalam sistem komputer. Windows dibuat oleh Microsoft yang merupakan suatu sistem operasi yang mengubah cara pengguna menggunakan komputer supaya lebih mudah dan ramah. Windows juga merupakan satu program yang memberikan reaksi kerja yang berdasarkan pada penggunaan ikon dan menu. Sistem operasi Windows memberikan pengaruh kerja yang ramah pengguna (user-friendly) yaitu berdasarkan kepada konsep antar-muka pengguna dengan cara grafik atau Graphical User Interface. Terdapat juga pada Windows aplikasi yang buat khusus untuk digunakan di dalam Windows seperti Notepad, Paint Bursh, Calender, Calculator dan lain-lain (Kurniawan dan Yahya, 2005).

\subsection{Linux}

Linux merupakan sistem operasi yang dikembangkan oleh seorang hacker Finlandia bernama Linus Bennedict Torvalds, sewaktu beliau masih menjadi mahasiswa di Helsinki University of Finland, pada umur 21 tahun. Berawal dari ketidak puasan akan sistem operasi Unix dan ketidakmampuan untuk membeli Unix, maka beliau memutuskan untuk menciptakan suatu sistem operasi yang bebas disebarluaskan. Proyek main-main yang dimulai dan selanjutnya diberitakan di internet menggugah para programer di seluruh dunia untuk membantu Linus mengembangkan Linux. Dan sampai tahun 2011 yang lalu, Linux telah berumur 20 tahun, suatu umur yang cukup dewasa. Sampai saat ini, Linux telah digunakan secara bebas untuk server ataupun desktop. Linux sendiri didistribusikan di bawah lisensi GPL.

\section{HASIL DAN PEMBAHASAN}

\subsection{Blok Diagram Sharing Data dan Printer}

NetBEUI merupakan protocol standar dalam lingkungan jaringan Microsoft, padahal nama dari I/O Redirection dari NetBEUI adalah SMB (Server Message Block) atau menurut istilah Microsoft CIFS (Common Internet File System). Dalam protocol standar Windows (NetBEUI) atau SMB atau CIFS, hal terpenting yang adalah kemampuan file atau print sharing, serta kemampuan browsing. Dengan munculnya NT, ditambahkan dua fitur tambahan, yakni authentication dan authorixation untuk setiap servis yang akan diakses terdapat NetBIOS sebagai pengenal komputer yang satu dengan yang lain, sedang I/O Redirection berfungsi sebagai fasilitas untuk memberikan share dan mengakses shared resource komputer lain.

Samba dibuat untuk menjalankan dua proses tersebut dengan transport protocol TCP/IP. Protocol NetBIOS digunakan untuk menyampaikan pesan, berjalan di atas protocol transport TCP/IP, sehingga disebut NBT (NetBIOS over TCP/IP). Perangkat lunak Samba sendiri merupakan kumpulan program yang mengimplementasikan protocol Server Message Block (SMB) untuk UNIX/LINUX. Protocol ini juga kerap disebut Common Internet System (CIFS), LanManager atau protocol NetBIOS (Purbo, 2002).

Sebelum melakukan sharing data dan printer pada sistem operasi Linux dan Windows, samba dapat membuat komputer dengan menggunakan sistem operasi yang berbeda dapat berbagi sumber daya (sharing data dan printer) dalam suatu jaringan. Adapun langkah-langkah agar Samba dapat melakukan berbagi sumber daya diantaranya adalah instal Samba, buat user Samba, konfigurasi Samba dan aktifkan Samba yang selanjutnya akan dijelaskan pada gambar 2 berikut ini : 


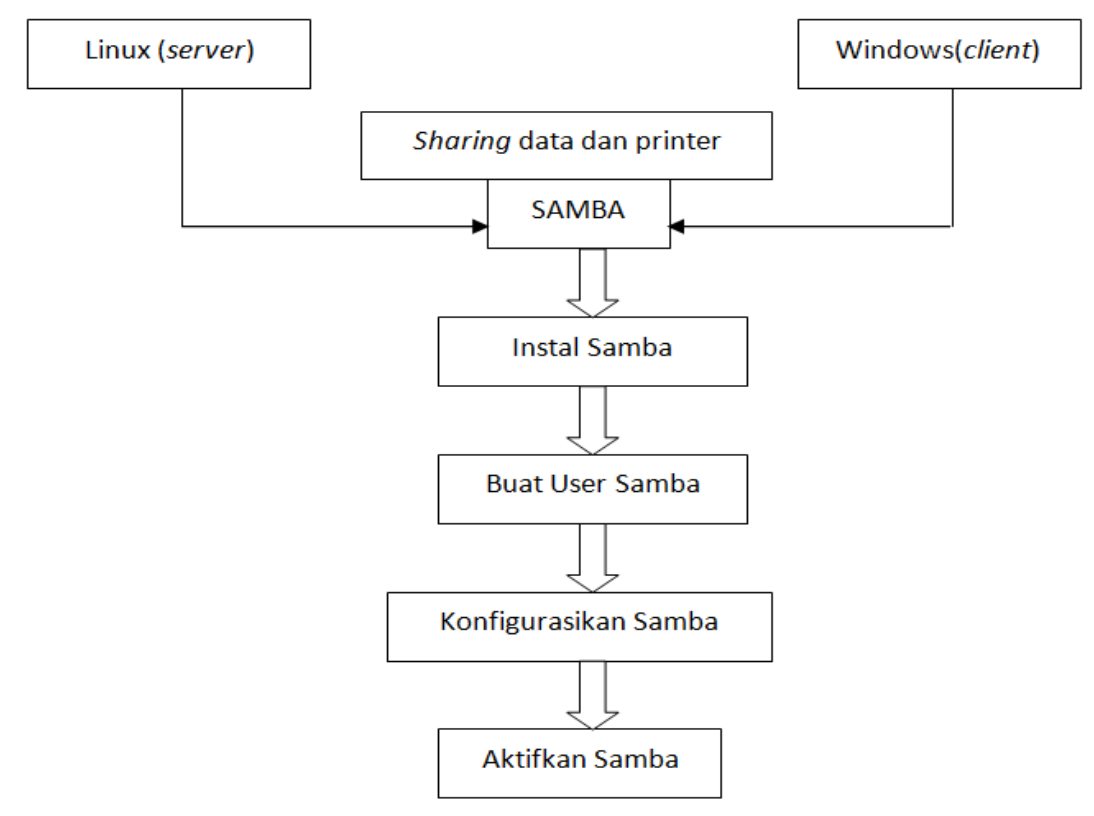

Gambar 2. Diagram Blok Samba

Kemampuan Samba yaitu dapat bekerja berfungsi pula sebagai master browser, baik dengan baik pada lingkungan jaringan local master browser maupun domain master berbasis Windows. Hampir semua fasilitas dari browser. Samba mendukung otentikasi Microsoft dapat dimanfaatkan secara optimal password teks biasa (plain text) maupun oleh Samba. Teknologi samba mendukung password terenskripsi (encrypted password) WINS Server, dapat berfungsi sebagai Primary (Purbo, 2002). Domain Controller (PDC), Samba dapat

Tabel 1. Kemampuan Samba

\begin{tabular}{|l|l|}
\hline Kemampuan & Dukungan \\
\hline File Server & Yes \\
\hline Printer Server & Yes \\
\hline Primary Domain Controller & Yes \\
\hline Backup Domain Controller & No \\
\hline Windows 95/98 Authentication & Yes \\
\hline Local Master Browser & Yes \\
\hline Local Backup Browser & No \\
\hline Domain Master Browser & Yes \\
\hline Primary WINS Server & Yes \\
\hline Secondary WINS Server & No \\
\hline
\end{tabular}

Komponen pendukung Samba adalah (Kurniawan dan Yahya, 2005) :

1. Smbclient, merupakan aplikasi PTP seperti yang disediakan oleh Unix ataupun Linux yang dapat digunakan untuk berhubungan dengan Samba share. Juga berbungsi sebagai klien yang memungkinkan kita mengakses share SMB dikomputer lain seperti jika kita mengakses resource yang ada di komputer lain lewat map network drive di jaringan Windows NT. 
2. Smbar, sebuah program untuk menyimpan data yang dapat dibagi kemedia penyimpanan external seperti tape, disk, dan lainnya.

3. Smbloockup, program yang menyediakan NetBIOS melalui TCP/IP name lookup. Utilitas untuk melakukan name query (meminta nama NetBIOS dari komputerkomputer yang sedang on-line) dari mesin Linux.

4. Smbpasswd, utilitas untuk mengubah SMB encrypted passwords, baik di server Samba maupun Windows NT. Sebuah program yang memperbolehkan admin untuk mengganti password yang digunakan Smba.

5. Smbstatus, program yang memperlihatkan client pada jaringan yang sedang terhubung Samba server. Utilitas untuk mengecek konfigurasi smb.cont.

6. Testprns, program yang bertugas untuk menguji berbagai jenis printer untuk mengetahui apakah printer tersebut telah dikenal oleh Samba daemon.

7. Swat Samba Web Administration Tool (SWAT), program bantu yang memberikan antarmuka model web untuk menadministrasi Samba, mempermudah mengedit file smb.conf, mengatur resource yang dibagi pakai dan melilhat status Samba terakhir.

\subsection{Instal Samba}

Layanan Samba hanya perlu diinstal pada sistem operasi Linux, Windows tidak memerlukan Samba karena telah menggunakan protokol SMB yang merupakan basis dari Samba. Untuk melakukan instalasi Samba, harus terlebih dahulu melakukan login sebagai root. Pada sebagian besar distribusi Linux, Samba telah diikutsertakan pada CD paket intalasi Linux. Untuk memeriksa apakah Samba telah terinstal pada Linux, gunakan perintah rpm sebagai berikut :

$$
\text { \#rpm-qa/grep samba }
$$

Apabila paket Samba telah terinstal perintah di atas akan memberikan hasil seperti berikut :

Samba-client-3.0.8-0pre1.3

Samba -3.0.8-0.pre1.3
System-config-samba-1.2.21-1

Samba-common-3.0.8-0.pre1.3

Jika Samba belum terinstal pada komputer atau ingin memperbaharui Samba ke versi yang lebih baru, harus dicari paket intalasi Samba terlebih dulu.

Jika melakukan upgrade Samba versi lama ke versi lebih baru jangan lupa untuk menguninstall versi lama terlebih dengan perintah sebagai berikut :

\section{\#rpm-e samba-x.x.x.i386.rpm}

Berikut adalah perintah untuk meng-upgrade Samba

\#rpm-u samba-x.x.x.i386.rpm

Jika kita memerlukan bantuan pilihan-pilihan yang bisa digunakan kita bisa mengakses manual online RPM dengan perintah :

\section{\#man rpm}

\subsection{Membuat User Samba}

Sebelum menjalankan dan konfigurasi (sharing data dan printer) terlebih dahulu dibuat user agar bisa mengakses layanan Samba. Untuk menambahkan sebuah user, gunakan perintah sebagai berikut :

\section{\#adduser namauser \#passwd namauser \\ Changginig password for useralderaan. \\ Nes UNIX password:[ketikkanpassword] \\ Passwd:all authentication tokens update Succesfully}

\subsection{Konfigurasi Samba}

Salah satu langkah untuk sharing data dan printer pada sistem operasi Linux dan Windows menggunakan Samba adalah melakukan konfigurasi Samba. Sebelum dilakukan konfigurasi terlebih dahulu direktori yang akan disharing misalnya /usr/lokal/share/samba buat direktori tersebut dengan cara :

\section{\#mkdir/usr/local/share/samba}

Konfigurasi samba dapat dilakukan melalui 3 cara yaitu konfigurasi dengan terminal(shell), xwindows dan browser(SWAT).

\subsection{Mengaktifkan Samba}

Ada dua daemon Samba yaitu smbd dan nmbd yang harus dijalankan apabila kita 
menginginkan Samba bisa bekerja dengan baik.

Perintah untuk mengaktifkan samba yaitu :

Untuk memulai Samba

\#/etc/rc.d/init.d/samba start

Untuk merestart Samba

\#/etc/rc.d/init.d/smb restart

Untuk stop Samba

\#/etc/rc.d/init.d/smb stop

Adapun cara untuk mengaktifkan SWAT adalah :

Untuk memulai SWAT

\#/etc/rc.d/init.d/xined start

Untuk merestart SWAT

\#/etc/rc.d/init.d/xinetd restart

Untuk stop SWAT

\#/etc/rc.d/init.d/xinetd stop

\section{KESIMPULAN}

File sharing dan Print sharing pada sistim operasi Linux dan sistem operasi Windows pada jaringan komputer menggunakan Samba dapat dilakukan dengan mudah dan teratur. Teknologi samba mendukung WINS Server, dapat berfungsi sebagai Primary Domain Controller (PDC), Samba dapat berfungsi pula sebagai master browser, baik local master browser maupun domain master browser. Samba mendukung otentikasi password teks biasa (plain text) maupun password terenskripsi (encrypted password). Samba dibuat untuk menjalankan dua proses tersebut dengan transport protocol TCP/IP. Protocol NetBIOS digunakan untuk menyampaikan pesan, berjalan di atas protocol transport $T C P / I P$, sehingga disebut NBT (NetBIOS over $T C P / I P)$. Perangkat lunak Samba sendiri merupakan kumpulan program yang mengimplementasikan protocol Server Message Block (SMB) untuk UNIX/LINUX. Protocol ini juga kerap disebut Common Internet System (CIFS), LanManager atau protocol NetBIOS.

\section{DAFTAR PUSTAKA}

Ahmad Yani, 2007, "Panduan Membangun Jaringan Komputer", Kawan Pustaka, Jakarta.

Alan Neibauer, 2001, "Small Business Solutions for Networking", Elex Media Komputindo, Jakarta.

Anis, Hariri, 2002. "Integrasi Jaringan UNIXWindows", PT. Gramedia, Jakarta.

Arianto, dkk, 2006, "Pengelolaan Jaringan Komputer di Linux", Salemba Infotek, Surabaya.

Eko Priyo Utomo, ST., 2006, "Pengantar Jaringan Komputer Bagi Pemula", Yrama Widya, Margahayu Permai, Bandung.

Kurniawan, Yahya, 2005, "Kiat Jitu Membangun Jaringan Linux dengan Windows", PT. Gramedia, Jakarta.

Mansfield, Nial, 2003, "Practical TCP/IP : Designing, Using, and Troubleshooting TCP/IP Network on Linux and Windows", Addison Wesley, Pearson Education, UK.

Iwan Binanto, 2007, "Membangun Jaringan Komputer Praktis Sehari-hari", Graha Ilmu, Candi Gebang Permai, Yogyakarta.

Purbo, W., Onno, 2002, "Samba Jembatan Windows dan Linux", PT. Gramedia, Jakarta. 